\title{
PENINGKATAN KEMAMPUAN PEMAHAMAN KONSEP MATEMATIKA MELALUI MODEL GUIDED DISCOVERY LEARNING BERBANTUAN PERMAINAN KAKI BIMA
}

\author{
Ismi Sumaryati $^{1}$, Ratri Rahayu ${ }^{2}$, dan Sri Utaminingsih ${ }^{3}$ \\ ${ }^{1,2}$ Prodi Pendidikan Guru Sekolah Dasar, Universitas Muria Kudus \\ ${ }^{3}$ Prodi Pendidikan Matematika, Universitas Muria Kudus
}

\begin{tabular}{l} 
Info Artikel \\
\hline Sejarah Artikel: \\
Diterima 24 Feb 2018 \\
Direvisi 20 Mar 2018 \\
Disetujui 20 Apr 2018 \\
\hline
\end{tabular}

Keywords: Mathematic Concept Comprehension, Guided Discovery

Learning Model, Kaki Bima Game

\section{Paper type:}

Research paper

\begin{abstract}
The purpose of this research are to describe the improvement of mathematics concept comprehension, the student learning activities, and teacher skills through guided discovery learning model by using kaki bima game on romawi numeric material. The design of this research was classroom action research that located in SDN Margorejo 01 Pati. The subject is the fourth graders consist of 25 students. The Independent variable is guided discovery learning model used kaki bima game and the dependent variable is mathematic concept comprehension. There are two cycles of the research. Each cycle consist of four steps, they are planning, action, observation, reflection. Data collection were used test, observation and documentation. The data analyses of the research are quantitative and qualitative. The result of this research showed that, (1) the mathematic concept comprehension of the fourth graders of SDN Margorejo 01 Pati with the mean of the cycle I is 62.08 with enough criteria; the students that can get score above passing grade is $48 \%$ and the mean of cycle II is improved with the score is 78.7 with higher criteria and the percentage is $80 \%$, (2) the students learning activities in cycle I got the mean score of 2.51 with the good criteria, and improved in cycle II with the mean score is 2.63 , (3) the teacher skill in cycle I got the mean score of 2.56 and improved in cycle II become 3.00 with the good criteria.
\end{abstract}

\begin{abstract}
Abstrak
Penelitian ini bertujuan untuk mendeskripsikan peningkatan kemampuan pemahaman konsep matematika, aktivitas belajar siswa, dan keterampilan guru mengajar dengan model guided discovery learning berbantuan permainan kaki bima pada materi bilangan romawi. Penelitian yang dilakukan adalah penelitian tindakan kelas yang dilaksanakan di SD N Margorejo 01 Pati dengan subjek 25 siswa kelas IV. Variabel bebas dalam penelitian ini yaitu model guided discovery learning berbantuan permainan kaki bima, sedangkan variabel terikat adalah pemahaman konsep matematika. Penelitian tindakan kelas ini berlangsung selama dua siklus, setiap siklus terdiri dari perencanaan, pelaksanaan, pengamatan/ observasi, dan refleksi. Teknik pengumpulan data menggunakan tes, observasi, dan dokumentasi. Analisis data yang digunakan adalah analisis data kuantitatif dan kualitatif.

Hasil penelitian menunjukkan bahwa (1) nilai rata-rata kemampuan pemahaman konsep matematika siswa kelas IV SD N Margorejo 01 Pati adalah 62,08 pada kriteria cukup dengan ketuntasan klasikal mencapai $48 \%$ pada siklus I meningkat pada siklus II dengan nilai rata-rata menjadi 78,7 pada kriteria tinggi dengan ketuntasan klasikal sebesar $80 \%$, (2) rata-rata aktivitas belajar siswa pada siklus I adalah 2,51 dengan kriteria baik meningkat pada siklus II menjadi 2,63 dengan kriteria baik, (3) rata-rata skor keterampilan guru pada siklus I adalah 2,56 dengan kriteria baik meningkat pada siklus II menjadi 3,00 dengan kriteria baik.
\end{abstract}

\footnotetext{
Alamat korespondensi:

Program Studi Pendidikan Matematika, Universitas Muria Kudus

Kampus UMK Gondangmanis, Bae Kudus Gd. L lantai 1 Ruang 2 PO BOX 53 Kudus

Tlp. (0291) 438229 Fax. (0291) 437198

E-mail: sumaryatiismi@gmail.com
} 


\section{PENDAHULUAN}

Matematika merupakan ilmu universal yang mendasari perkembangan teknologi modern, mempunyai peran penting dalam berbagai disiplin dan memajukan daya pikir manusia (Depdiknas, 2006). Hal ini menunjukkan bahwa matematika menjadi dasar perkembangan teknologi modern dan menjadikan manusia berpikir kritis. Penguasaan dan penciptaan teknologi di masa depan memerlukan penguasaan matematika sejak dini. Oleh karena itu, pelajaran matematika perlu diberikan kepada siswa mulai dari sekolah dasar untuk dibekali dengan kemampuan berpikir logis, analitis, sistematis, kritis, dan kreatif, serta kemampuan bekerjasama (Depdiknas, 2006). Tujuan pemberian pelajaran matematika agar siswa dapat memiliki kemampuan memperoleh, mengelola, dan memanfaatkan informasi untuk bertahan hidup pada keadaan yang selalu berubah sesuai dengan perkembangan zaman.

Hasil studi TIMSS pada matematika tahun 2015, Indonesia berada di urutan 45 dari 50 negara dengan skor rata-rata 397 , sedangkan skor rata-rata internasional adalah 500 dengan target populasinya kelas 4 SD/MI (Mullis, 2015). Dari hasil studi TIMSS dapat diketahui bahwa siswa Indonesia menguasai soal-soal yang bersifat rutin, komputasi sederhana, serta mengukur pengetahuan akan fakta yang berkonteks keseharian. Selain itu, siswa Indonesia masih mempunyai kemampuan yang lemah dalam mengintegrasikan informasi, menarik simpulan, serta menggeneralisir pengetahuan yang dimiliki ke hal-hal yang lain. Permasalahan tersebut dikarenakan pendidikan di Indonesia hanya menekankan pada hasil (produk) tanpa mengajak siswa untuk membangun dan memahami suatu konsep terhadap penyelesaian soal. Dengan demikian, tujuan mata pelajaran matematika sekolah dasar di Indonesia yang salah satunya siswa memiliki kemampuan pemahaman konsep matematika masih belum tercapai.

Pada jenjang sekolah dasar, pemahaman konsep matematika perlu ditanamkan dengan baik kepada siswa terlebih mereka masih berpikir konkret. Apabila pemahaman konsep siswa rendah, maka siswa akan kesulitan dalam menyelesaikan persoalan matematika sehingga berdampak pada prestasi belajarnya. Heruman (2010: 3) menjelaskan bahwa pemahaman konsep merupakan pembelajaran lanjutan yang bertujuan agar siswa lebih memahami suatu konsep matematika. Hal ini juga diungkapkan Afrilianto (2012:193) yang menyatakan bahwa pemahaman konsep adalah kemampuan dalam memahami konsep, operasi dan relasi dalam matematika. Di lapangan, masih banyak permasalahan-permasalahan dalam pembelajaran matematika khususnya dalam kemampuan pemahaman konsep.

Keadaan demikian terjadi dalam pembelajaran matematika di kelas IV SD Negeri Margorejo 01 Pati. Berdasarkan hasil rata-rata nilai pra siklus materi bilangan 25 siswa yaitu 31,33 yang menunjukkan pemahaman konsep matematika siswa pada kualifikasi rendah Sedangkan untuk ketuntasan belajar klasikal, terdapat 2 siswa (8\%) yang tuntas sedangkan 23 siswa $(92 \%)$ belum tuntas. Suatu pembelajaran dikatakan berhasil jika minimal 75\% dari jumlah siswa dalam kelas sudah tuntas belajar. Sejalan dengan hasil wawancara yang dilakukan peneliti dengan guru kelas IV SD Negeri Margorejo 01 Pati yang menjelaskan bahwa pemahaman siswa masih kurang pada materi bilangan khususnya bilangan romawi.

Kurangnya pemahaman konsep di SD Negeri Margoerejo 01 Pati disebabkan penggunaan bilangan romawi pada kehidupan sehari-hari yang jarang dilakukan. Untuk membantu menyampaikan materi, guru sudah menggunakan media berupa power point. Namun penggunaan media tersebut tidak berjalan optimal karena tidak melibatkan siswa secara langsung. Selain penggunaan media, guru sudah menggunakan metode/model dalam pembelajaran. Sesekali guru melakukan tanya jawab terhadap siswa, tetapi siswa cenderung pasif dan tidak merespon pertanyaan guru. Apabila ada materi yang belum dimengerti, siswa masih takut untuk bertanya. Siswa juga kurang tertarik terhadap pejelasan yang disampaikan oleh guru sehingga siswa merasa bosan dan berbicara sendiri dengan temannya saat pembelajaran berlangsung. Sehingga, suasana pembelajaran di kelas menjadi tidak menyenangkan.

Berdasarkan permasalahan tersebut, peneliti melakukan penelitian tindakan kelas di SD Negeri Margorejo. Tujuan penelitian tersebut adalah untuk mendeskripsikan peningkatan kemampuan pemahaman konsep matematika materi bilangan romawi pada siswa kelas IV SD Negeri Margorejo 01 Pati, mendeskripsikan peningkatan aktivitas belajar siswa kelas IV, dan mendeskripsikan keterampilan guru.

Solusi yang ditawarkan untuk mengatasi permasalahan tersebut dengan menerapkan model pembelajaran guided discovery learning dengan berbantuan permainan kaki bima. Model guided discovery learning merupakan salah satu model pembelajaran yang melatih dan membimbing siswa untuk belajar, memperoleh pengetahuan, dan membangun konsep yang 
mereka temukan untuk dirinya sendiri. Pembelajaran penemuan terbimbing (guided discovery) merupakan pembelajaran yang melatih dan membimbing siswa untuk belajar memperoleh pengetahuan, dan membangun konsep-konsep yang mereka temukan untuk diri sendiri (Pardede, dkk. 2016). Pembelajaranpenemuan terbimbinglebih menekankan pada siswa untuk terlibat secara langsung dalam menyelidiki dan menarik kesimpulan dan guru sebagai penunjuk jalan membantu siswa agar mempergunakan ide, konsep dan ketrampilan yang sudah mereka pelajari untuk menemukan pengetahuan yang baru (Kanzunnudin dkk., 2013). Selain menggunakan model, penemuan konsep matematika dapat dilakukan dengan bantuan permainan.

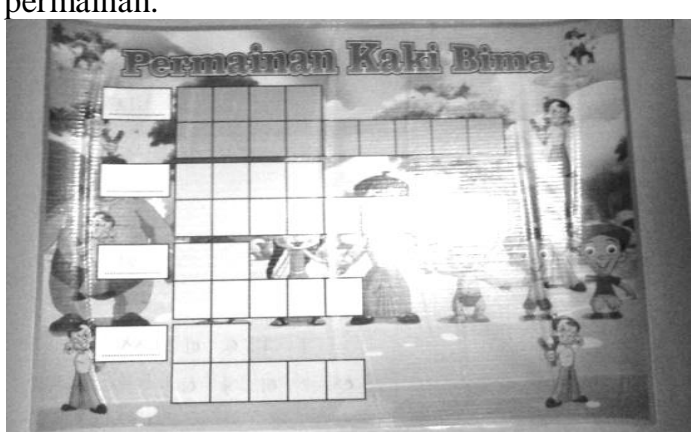

Gambar 1 Permainan Kaki Bima

Permainan kaki bima merupakan permainan teki teki yang dipadukan dalam materi bilangan romawi. Pramesti (2015) mengungkapkan bahwa teka-teki silang berisi kolom menurun dan mendatar. Kolom-kolom tersebut disusun berdasarkan huruf yang dibutuhkan. Permainan kaki bima terdiri dari 2 benda yaitu lembar teka-teki dan kartu bilangan. Pada lembar teka-teki terdapat kolom-kolom mendatar yang nantinya disusun berdasarkan huruf romawi atau bilangan asli yang dibutuhkan. Huruf romawi dan bilangan asli dikemas dalam bentuk kartu bilangan. Kartu bilangan tersebut juga dilengkapi tanda $(+,-,=$, dan kurung). Permainan ini diharapkan dapat mempermudah siswa menemukan konsep cara membaca maupun menulis bilangan romawi.

Model guided discovery learning dipadukan dengan permainan kaki bima dalam meningkatkan pemahaman konsep siswa materi bilangan romawi. Model ini memiliki lima tahapan antara lain merumuskan masalah, menganalisis masalah, menyusun konjektur (perkiraan), menarik kesimpulan, dan memberikan evaluasi berupa soal latihan. Penggunaan permainan kaki bima dilakukan pada tahap menganalisis masalah sampai dengan menarik kesimpulan. Pada tahap menganalisis masalah dan menyusun konjektur, siswa akan menyusun strategi untuk mengisi kolom-kolom permainan kaki bima dengan menggunakan kartu bilangan. Pada tahap menarik kesimpulan, siswa akan mempresentasikan hasil kerjanya, kemudian menyimpulkan hasil kegiatan diskusi yang telah dilaksanakan. Guru memberikan evaluasi berupa soal latihan untuk mengetahui seberapa besar pemahaman siswa terhadap kegiatan pembelajaran yang telah berlangsung. Setiap tahapan, guru selalu mengarahkan dan membimbing siswa menggunakan permainan kaki bima agar tidak mengalami kesulitan. Melalui penerapan tersebut, siswa akan terlibat langsung dalam menemukan dan memahami konsep cara membaca maupun menulis bilangan romawi.

Berdasarkan paparan permasalahan di atas, maka peneliti akan mengadakan penelitian tindakan kelas yang disesuaikan dengan permasalahan pada materi pelajaran matematika dengan judul "Peningkatan Kemampuan Pemahaman Konsep Matematika Siswa SD Melalui Model Guided Discovery Learning Berbantuan Permainan Kaki Bima”.

\section{METODE PENELITIAN}

Jenis penelitian ini adalah penelitian tindakan kelas (PTK). Dalam penelitian ini, peneliti menggunakan model penelitian tindakan kelas yang dikemukakan oleh Kemmis \& Mc Taggart. Secara garis besar terdapat empat tahapan yang lazim dilalui yaitu (1) perencanaan, (2) pelaksanaan, (3) pengamatan, dan (4) refleksi (Arikunto, 2011: 137). Menurut Sugiyono (2013: 38) menyatakan bahwa, variabel merupakan suatu atribut atau sifat atau nilai dari orang, objek atau kegiatan yang mempunyai variasi tertentu yang ditetapkan oleh peneliti untuk dipelajari dan ditarik kesimpulannya.Variabel bebas pada penelitian ini yaitu model Guided Discovery Learning, sedangkan variabel terikatnya adalah pemahaman konsep matematika siswa.

Teknik pengumpulan data yang digunakan pada penelitian ini berupa tes, observasi, dan dokumentasi. Sedangkan instrumen yang digunakan pada penelitan ini berupa lembar observasi, lembar tes uraian, dan dokumentasi. Teknik analisis data yang digunakan berupa teknik analisis data kuantitatif dan keualitatif. Analisis data kuantitatif bertujuan untuk mengetahui peningkatan kemampuan pemahaman konsep matematika siswa kelas IV SDN Margorejo 01 pada materi membaca dan menulis bilangan romawi melalui penerapan model Guided Discovery Learning berbantuan permainan kaki bima. 
Cara perhitungan tingkat pemahaman konsep matematika yang dicapai siswa dapat dirumuskan sebagai berikut.

nilai $=\frac{\text { skor jawaban siswa }}{\text { skor maksimal }} \quad \mathrm{x} 100$

Selanjutnya kemampuan pemahaman konsep matematika tersebut dapat dikualifikasikan pada Tabel 1 .

Tabel 1 Kualifikasi Pemahaman Konsep Matematika

\begin{tabular}{cc}
\hline Nilai akhir & Kriteria \\
\hline $75-100$ & Tinggi \\
$50-74,99$ & Cukup \\
$25-49,99$ & Rendah \\
$0-24,99$ & Sangat rendah \\
\hline & Sumber: Arikunto $(2013: 25)$
\end{tabular}

Ketuntasan belajar individu diperoleh berdasarkan jumlah nilai yang diperoleh siswa. Nilai yang diperoleh siswa dihitung menggunakan rumus sebagai berikut.

$$
\begin{array}{|c|c|}
\text { nilai }=\frac{\text { jumlah skoryang diperoleh }}{\text { skor maksimal }} x 100 \\
\text { Hasil perhitungan kemudian di }
\end{array}
$$
bandingkan dengan kriteria ketuntansan belajar siswa yang dikategorikan kedalam dua kategori yaitu tuntas dan tidak tuntas. Kriteria Ketuntasan Minimal (KKM) yang ditetapkan oleh SD Negeri Margorejo 01 adalah 75. Siswa dinyatakan tuntas apabilai nilai tes evaluasi yang diperoleh pada akhir siklus $\geq 75$, sebaliknya siswa dinyatakan tidak tuntas apabila nilai tes yang diperoleh $<75$.

Ketuntasan belajar klasikal diperoleh berdasarkan jumlah siswa yang tuntas dibagi jumlah siswa seluruh kelas IV. Presentase ketuntasan belajar kalsikal, dengan menggunakan rumus sebagai berikut:

$$
\mathrm{P}=\frac{\text { Esiswa yang twntas belajar }}{\text { Esiswa }} \times 100 \%
$$

Suatu kelas dikatakan tuntas belajarnya, apabila di dalam kelas tersebut terdapat $\geq 75 \%$ siswa yang tuntas belajarnya dalam pembelajaran matematika.

Dalam penelitian ini, data kualitatif berupa data hasil observasi aktivitas belajar siswa serta keterampilan guru dalam mengajar. Analisis data kualitatif yang digunakan adalah analisis deskriptif. Berikut penyajian data kualitatif yang digunakan dalam penelitian ini pada Tabel 2.

Tabel 2 Rekapitulasi Penentuan Skor Aktivitas Belajar Siswa dan Keterampilan Guru

\begin{tabular}{cc}
\hline Skor & Kriteria Penilaian \\
\hline 4 & Sangat baik \\
3 & Baik \\
2 & Cukup baik \\
1 & Kurang baik \\
\hline & Sumber: Sugiyono (2010: 141$)$
\end{tabular}

Setelah melakukan rekapitulasi, kemudian mencari skor rata-rata dengan rumus sebagaai berikut.

$$
\text { Skor rata }- \text { rata }=\frac{\text { skor maksimal }}{\text { skor perolehan }}
$$

Hasil perhitungan kemudian disimpulkan pada Tabel 3.

Tabel 3 Kriteria Skor Aktivitas Belajar Matematika Siswa dan Keterampilan Guru

\begin{tabular}{cc}
\hline Skor & Kriteria \\
\hline $1<$ skor rata-rata $\leq 1,75$ & kurang baik \\
$1,75<$ skor rata-rata $\leq 2,5$ & cukup baik \\
$2,5<$ skor rata-rata $\leq 3,25$ & baik \\
$3,25<$ skor rata-rata $\leq 4$ & sangat baik \\
\hline & Sumber: Sugiyono $(2010: 141)$
\end{tabular}

Indikator keberhasilan pada penelitian ini sebagai berikut.

1. Nilai rata-rata kelas untuk tes kemampuan pemahaman konsep matematika siswa $\geq 75$ pada kriteria tinggi dengan presentase ketuntasan belajar klasikal $\geq 75 \%$.

2. Skor rata-rata aktivitas belajar siswa kelas IV SD Negeri Margorejo 01 Pati pada materi bilangan romawi melalui penerapan model guided discovery learning berbantuan permainan kaki bima > 2,5 dengan kriteria minimal baik.

3. Skor rata-rata keterampilan guru dalam kegiatan pembelajaran pada siswa kelas IV SD Negeri Margorejo 01 Pati materi bilangan romawi melalui penarapan model guided discovery learning berbantuan permainan kaki bima $>2,5$ dengan kriteria minimal baik.

\section{HASIL DAN PEMBAHASAN}

Penelitian ini dilaksanakan dalam dua siklus. Setiap akhir siklus dilaksanakan evaluasi untuk mengetahui peningkatan pemahaman konsep matematika siswa kelas IV SD Negeri Margorejo 01 Pati. Hasil tes kemampuan pemahaman konsep matematikas siswa kelas IV SD Negeri Margorejo 01 Pati pada siklus I memperoleh rata-rata 62,08 pada kriteria cukup.

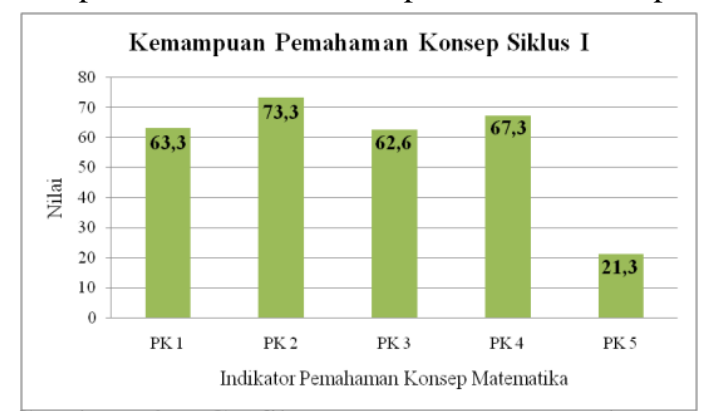

Gambar 2. Grafik Kemampuan Pemahaman Konsep Matematika Setiap Indikator Siklus I 
Berdasarkan Gambar 2, dapat diketahui bahwa hasil tes evaluasi kemampuan pemahaman konsep matematika siswa kelas IV SD Negeri Margorejo 01 Pati siklus I pada indikator kemampuan menyatakan ulang sebuah konsep sebesar 63,3 pada kriteria cukup, indikator kemampuan memberi contoh dan bukan non contoh sebesar 73,3 pada kriteria cukup, indikator kemampuan menyajikan konsep dalam berbagai bentuk representasi matematika sebesar 62,6 pada kriteria cukup, indikator kemampuan menggunakan, memanfaatkan dan memilih prosedur tertentu sebesar 67,3 pada kriteria cukup dan indikator kemampuan mengaplikasikan konsep/algoritma ke pemecahan masalah sebesar 21,3 pada kriteria sangat rendah.

Berdasarkan hasil tersebut, kelima indikator pemahaman konsep tersebut perlu diperbaiki pada siklus II. Sebab, rata-rata nilai kelima indikator tersebut belum mencapai ratarata nilai minimal 75 pada kriteria tinggi. Pada saat proses pembelajaran, kemampuan menyatakan ulang bilangan romawi menjadi bilangan asli pada tahap menganalisis masalahmasih dilakukan beberapa siswa saat mengaplikasikan kartu bilangan di permainan kaki bima.Pada kemampuan memberi contoh dan bukan contoh, kebanyakan siswa belum mampu membedakan cara membaca bilangan romawi yang tepat dan tidak tepat saat menyusun konjektur.

Siswa masih belum dapat memilih tanda yang tepat dan tidak membalik bilangan saat menggunakan tanda (-). Pada kemampuan menyajikan konsep, masih ada beberapa siswa belum mampu menyajikan konsep bilangan romawi ke dalam operasi penjumlahan dan pengurangan pada tahap menyusun konjektur. Sedangkan pada kemampuan menggunakan prosedur tertentu, masih adanya siswa yang salah pada tahap memberikan evaluasi karena kurang teliti. Sedangkan, kemampuan mengaplikasikan konsep ke pemecahan masalah, siswa masih belum paham mengenai soal yang berbentuk soal cerita.

Tabel 4 Hasil Nilai Tes Kemampuan Pemahaman Konsep Matematika Siklus I

\begin{tabular}{cccc}
\hline Nilai & Ketuntasan & $\begin{array}{c}\text { Jumlah } \\
\text { Siswa }\end{array}$ & Persentase \\
\hline$\geq 75$ & Tuntas & 12 & $48 \%$ \\
$<75$ & Tidak Tuntas & 13 & $52 \%$ \\
\hline & Total & 25 & $100 \%$ \\
\hline
\end{tabular}

Berdasarkan Tabel 4, dapat diketahui bahwa siswa yang telah mencapai ketuntasan belajar berjumlah 12 siswa dengan presentase mencapai $48 \%$, sedangkan siswa yang belum mencapai ketuntasan belajar berjumlah 13 siswa dengan presentase $52 \%$ sehingga belum mencapai indikator keberhasilan yaitu $75 \%$ dan perlu perbaikan pada siklus II.

Hasil tes kemampuan pemahaman konsep matematikas siswa kelas IV SD Negeri Margorejo 01 Pati pada siklus II memperoleh rata-rata 78,7 pada kriteria tinggi.

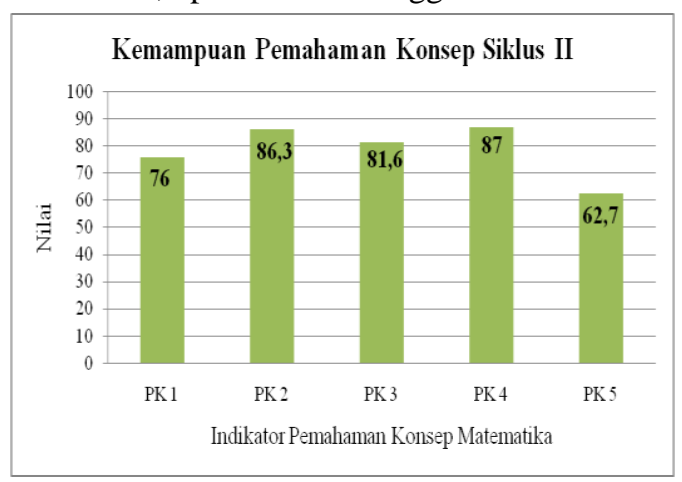

Gambar 3. Grafik Kemampuan Pemahaman Konsep Matematika Setiap Indikator Siklus II

Berdasarkan Gambar 3 dapat diketahui bahwa, rata-rata hasil tes evaluasi kemampuan pemahaman konsep matematika SD Negeri Margorejo 01 Pati pada siklus II pada indikator kemampuan menyatakan ulang sebuah konsep sebesar 76 dengan kriteria tinggi, indikator kemampuan memberi contoh dan bukan non contoh sebesar 86,3 dengan kriteria tinggi, indikator kemampuan menyajikan konsep dalam berbagai bentuk representasi matematika sebesar 81,6 dengan kriteria tinggi, indikator kemampuan menggunakan, memanfaatkan dan memilih prosedur tertentu sebesar 87 dengan kriteria tinggi, dan indikator kemampuan mengaplikasikan konsep/algoritma ke pemecahan masalah sebesar 62,7 dengan kriteria cukup.

Pada siklus II, rata-rata nilai keempat indikator tersebut sudah mencapai rata-rata nilai minimal 75 pada kriteria tinggi, dan satu indikator yang belum tercapai yaitu kemampuan mengaplikasikan konsep/algoritma ke pemecahan masalah. Pada saat proses pembelajaran, kemampuan menyatakan ulang bilangan asli menjadi bilangan romawi siswa dapat meningkat, hal ini disebabkan karena peneliti melakukan perbaikan pada siklus II dengan memberikan penjelasan mengenai konsep menulis bilangan romawi dengan bahasa yang mudah dipahami siswa serta memberikan catatan kepada siswa agar siswa lebih mudah mengingat pada saat penjelasan materi.

Pada kemampuan memberi contoh dan bukan contoh, kebanyakan siswa sudah mampu membedakan cara menulis bilangan romawi yang tepat dan tidak tepat saat menyusun konjektur. Siswa mampu memilih tanda yang 
tepat dan membalik bilangan saat menggunakan tanda (-).

Peneliti melakukan perbaikan dengan pemberian pertanyaan secara lisan dan memberikan kesempatan kepada siswa untuk bertanya mengenai materi tersebut jika masih belum pahamPada kemampuan menyajikan konsep dan kemampuan menggunakan prosedur tertentu, siswa sudah mampu dan teliti saat mengerjakan soal latihan pada tahap memberikan evaluasi. Sedangkan, kemampuan mengaplikasikan konsep ke pemecahan masalah adanya peningkatan skor dari siklus I ke siklus II namun masih belum mencapai indikator keberhasilan yang ditentukan. Penyebabnya adalah siswa masih belum paham mengenai soal yang berbentuk soal cerita pada saat mengerjakan soal akhir siklus I maupun siklus II.

Tabel 5 Hasil Nilai Tes Kemampuan Pemahaman Konsep Matematika Siklus II

\begin{tabular}{llll}
\hline Nilai & Ketuntasan & $\begin{array}{l}\text { Jumlah } \\
\text { Siswa }\end{array}$ & Persentase \\
& & 20 & $80 \%$ \\
$\geq 75$ & Tuntas & 5 & $20 \%$ \\
\hline$<5$ & Tidak Tuntas & 25 & $100 \%$ \\
\hline & Total & 25 &
\end{tabular}

Berdasarkan Tabel 5 menunjukkan bahwa siswa yang telah mencapai ketuntasan belajar berjumlah 20 siswa dengan psersentase sebesar $80 \%$, sedangkan siswa yang belum mencapai ketuntasan belajar berjumlah 5 siswa dengan persentase $20 \%$. Persentase ketuntasan belajar klasikal siswa kelas IV SD N Margorejo 01 Pati sudah mencapai indikator keberhasilan yaitu $75 \%$.

Tabel 6 Peningkatan Pemahaman Konsep Matematika

\begin{tabular}{cccccccc}
\hline KK & Ketuntasan & Pra Siklus & Siklus I & \multicolumn{3}{c}{ Siklus II } \\
\cline { 3 - 8 } M & Belajar & $\begin{array}{c}\text { Jumlah } \\
\text { Siswa }\end{array}$ & $\%$ & $\begin{array}{c}\text { Jumlah } \\
\text { Siswa }\end{array}$ & $\%$ & $\begin{array}{c}\text { Jumlah } \\
\text { Siswa }\end{array}$ & $\%$ \\
\hline$\geq 75$ & Tuntas & 2 & 8 & 12 & 48 & 20 & 80 \\
& & & $\%$ & & $\%$ & & $\%$ \\
\hline$<75$ & Tidak & 23 & 2 & 13 & 52 & 5 & 20 \\
& Tuntas & & $\%$ & & $\%$ & & $\%$ \\
\hline
\end{tabular}

Berdasarkan Tabel 6 menunjukkan bahwa, pada pra siklus siswa yang dapat mencapai nilai KKM sebanyak 2 siswa dengan persentase $8 \%$, sedangkan siswa yang tidak mencapai KKM sebanyak 23 siswa dengan persentase $92 \%$. pada siklus I sebanyak 12 siswa yang dapat mencapai KKM dengan persentase $48 \%$, sedangkan sebanyak 13 siswa yang tidak mencapai KKM dengan persentase 52\%. Pada siklus II, siswa yang tuntas atau mencapai KKM sebanyak 20 siswa dengan persentase $80 \%$, sedangkan siswa yang tidak tuntas atau tidak mencapai KKM sebanyak 5 siswa dengan persentase $20 \%$. Jadi, persentase ketuntasan dari siklus I ke siklus II terdapat peningkatan pemahaman konsep matematika sebesar $32 \%$.
Hasil penelitian dari siklus I sampai dengan siklus II, kemampuan pemahaman konsep matematika siswa meningkat disebabkan adanya penerapan model guided discovery learning berbantuan permainan kaki bima. Model guided discovery learning melatih siswa untuk terlibat langsung dalam menemukan suatu konsep dengan bimbingan dan arahan dari guru. Sejalan dengan Kanzunnudin, dkk. (2013) yang menjelaskan bahwa pembelajaran penemuan terbimbing (guided discovery learning) lebih menekankan pada siswa untuk terlibat langsung dalam menyelidiki dan menarik kesimpulan dan guru sebagai penunjuk jalan membantu siswa agar mempergunakan ide, konsep dan keterampilan yang sudah mereka pelajari untuk menemukan pengetahuan yang baru.

Hasil observasi aktivitas belajar siswa pada siklus I memperoleh rata-rata akhir 2,51 pada kriteria baik. Sedangkan pada siklus II memperoleh rata-rata akhir 2,63 dengan kriteria baik. Sehingga, hasil rata-rata akhir siklus I menuju siklus II mengalami peningkatan aktivitas belajar siswa sebesar 0,14. Rata-rata skor aktivitas belajar siswa pada siklus II sudah mencapai indikator keberhasilan yang ditentukan yaitu minimal > 2,50 dengan kriteria baik sehingga tidak perlu perbaikan lagi dan penelitian ini berhenti pada siklus II.

Aktivitas belajar siswa dari siklus I sampai dengan siklus II mengalami peningkatan. Hal ini disebabkan karena adanya penerapan model guided discovery learning berbantuan permainan kaki bima. Permainan ini memiliki peranan penting dalam aktivitas siswa menemukan konsep bilangan romawi.Siswa terlibat secara langsung dalam penggunaan permainan kaki bima, sehingga suasana belajar siswa menjadi lebih menyenangkan. Sebagaimana pendapat Pitadjeng (dalam Sutrisno 2014: 226) yang menyatakan bahwa belajar akan efektif jika dilakukan dalam suasana yang menyenangkan, sedangkan orang yang belajar akan merasa senang jika memahami apa yang dipelajari.

Sedangkan, hasil observasi keterampilan guru pada siklus I memperoleh rata-rata akhir sebesar 2,56 dengan kriteria baik, sedangkan pada siklus II memperoleh rata-rata akhir sebesar 3,00 dengan kriteria baik. Sehingga dari siklus I menuju siklus II, skor rata-rata keterampilan guru mengalami peningkatan sebesar 0, 28. Ratarata skor keterampilan guru mencapai rata-rata skor minimal > 2,50 dengan kriteria baik. Dengan demikian, tidak perlu perbaikan lagi dan penelitian ini berhenti pada siklus II.

Hasil penelitian dari siklus I sampai dengan siklus II, keterampilan guru mengalami 
peningkatan yang disebabkan adanya penerapan model guided discovery learning berbantuan permainan kaki bima. Melalui penemuan terbimbing ini, terjadi interaksi antara guru dengan siswa karena peran guru tidak hanya sebagai pemberi masalah akan tetapi juga sebagai pembimbing yang membantu dan mengarahkan siswa menemukan konsep bilangan romawi. sejalan dengan pendapat Saila (2015) yang menyatakan bahwa metode penemuan terbimbing merupakan metode pembelajaran yang melibatkan serangkaian dialog/interaksi antara guru dan siswa.

\section{SIMPULAN}

Hasil penelitian ini diharapkan dapat memberikan kontribusi bagi sekolah berupa permainan edukatif dalam kaitannya dengan peningkatan kualitas pembelajaran matematika. Hasil penelitian ini juga dapat bermanfaat secara praktis bagi guru dalam menerapkan model guided discovery learning berbantuan permainan kaki bima untuk meningkatkan pemahaman konsep matematika siswa pada materi bilangan romawi. selain itu, penelitian ini dapat meningkatkan aktivitas belajar siswa dan menciptkan suasana belajar yang menyenangkan dalm pembelajaran matematika.

Berdasarkan penelitian yang telah dilakukan, dapat disimpulkan bahwa penerapan model guided discovery learning berbantuan permainan kaki bima dapat meningkatkan kemampuan pemahaman konsep materi bilangan romawi yaitu membaca dan menulis bilangan romawi. Kemampuan pemahaman konsep matematika siswa pada materi bilangan romawi memperoleh nilai rata-rata kelas sebesar 62,08 dengan kriteria cukup dengan presentase ketuntasan belajar klasikal mencapai $48 \%$ pada siklus I. Sedangkan, pada siklus II mengalami peningkatan nilai rata-rata kelas menjadi 78,7 dengan kriteria tinggi dengan presentase ketuntasan belajar klasikal sebesar $80 \%$.

Selain itu, aktivitas belajar siswa dalam pembelajaran matematika pada siklus I memperoleh rata-rata skor 2,51 dengan kriteria baik dan meningkat pada siklus II menjadi 2,63 dengan kriteria baik. sedangkan, keterampilan guru dalam menerapkan model guided discovery learning berbantuan permainan kaki bima pada pembelajaran matematika memperoleh rata-rata skor 2,56 pada siklus I dan meningkat pada siklus II menjadi 3,00 dengan kriteria baik.

\section{UCAPAN TERIMA KASIH}

Ucapan terima kasih kepada (1) Dr. Slamet Utomo, M.Pd. selaku dekan FKIP UMK; (2) Ika Oktavianti, M.Pd., ketua Prodi PGSD
UMK.; (3) Kepala SD Negeri Margorejo 01 Pati, Siti Mahmudah, S.Pd.; (4) Bambang Suswanto, S.Pd., guru kelas IV SD Negeri Margorejo 01 Pati; (5) seluruh siswa kelas IV SD Negeri Margorejo 01 Pati; (6) seluruh pihak yang telah membantu dalam penelitian ini.

\section{DAFTAR PUSTAKA}

Afrilianto. 2012. Peningkatan Pemahaman Konsep dan Kompetensi Matematis Siswa SMP Dengan Pendekatan metaphorical thinking.. Jurnal Ilmiah STKIP Siliwangi, 1 (2): 192-203.

Arikunto, Suharsimi. 2013. Manajemen Penelitian. Jakarta: PT. Rineka Cipta.

Aqib, Zainal. 2011. Penelitian Tindakan Kelas untuk Guru SD, SLB, dan TK. Bandung: Yrama Widya.

Depdiknas. 2006. Kurikulum Tingkat Satuan Pendidikan: Standar Isi Mata Pelajaran Matematika. Jakarta: Depdiknas.

Heruman. 2010. Model Pembelajaran Matematika di Sekolah Dasar. Bandung: Remaja Rosdakarya.

Kanzunnudin, dkk. 2013. Peranan Metode Guided Discovery Learning Berbantuan Lembar Kegiatan Ssiswa Dalam Peningkatan Prestasi Belajar Matematika. Prosiding Seminar Peranan Guru Profesional dan Berkarakter dalam Pembangunan Sumber Daya Manusia di Era Global Universitas Muria Kudus Tahun 2013, 118-133.

Mullis, I dkk. 2015. TIMSS Advanced 2015 International Results in Advanced Mathematics and Physics. Chesnut Hills: Boston College.

Pardede, Erna dan Suyanti. R.D. 2016. Efek Model Pembelajaran Guided Discovery Berbasis Kolaborasi Dengan Media Flash Terhadap Keterampilan Proses Sains dan Hasil Belajar Kognitif Tinggi Fisika Siswa SMA. Jurnal Pendidikan Fisika, 5 (1): 12-17.

Pramesti, Utami Dewi. 2015. Peningkatan Penguasaan Kosakata Bahasa Indonesia Dalam Keterampilan Membaca Melalui Teka-Teki Silang. Jurnal Puitika, 11 (1): 82-93.

Saila, Nurul. 2015. Penerapan Pembelajaran Kooperatif Metode Guided Discovery Meningkatkan Keaktifan Siswa Belajar Matematika. Prosiding Seminar Nasional Matematika dan Pendidikan Matematika. Universitas Negeri Yogyakarta Tahun 2015, 639-644.

Sugiyono, Prof. Dr. 2010. Statistika Untuk Penelitian. Bandung: Alfabeta. 
Sutrisno, Hidayah. 2014. Peningkatan Hasil Belajar Siswa Pada Materi Operasi Hitung Bilangan Berpangkat Dengan Media Molikur-13 di kelas VI SD 10 Malinau Kota. J-TEQIP, 1 (2): 226-238. 